\title{
The Evaluation of Cognitive Impairment and Relevant Factors in Patients with Chronic Obstructive Pulmonary Disease
}

\author{
Jing Li Yun Huang Guang-He Fei \\ Pulmonary Department, First Affiliated Hospital of Anhui Medical University, Hefei, China
}

For editorial comment see p. 96

\section{Key Words}

Arterial blood gas $\cdot$ Chronic obstructive pulmonary

disease $\cdot$ Clusterin $\cdot$ Cognitive performance $\cdot$ Pulmonary

function

\begin{abstract}
Background:Chronic obstructive pulmonary disease (COPD) is understood to be a complex multicomponent disorder. The impairment of cognition is lasting and profound. However, the pattern of the cognitive decline and potentially adverse factors are poorly understood. Objectives: To evaluate the cognitive performances and the relevant factors in COPD patients and to investigate the relationship between cognition deficits and the classification of severity of the disease. Methods: Twenty-seven mild-to-moderate COPD patients, 35 severe COPD patients and 27 control subjects were recruited. Cognitive states were investigated by the Mini-Mental State Examination (MMSE). Pulmonary function, arterial blood gas and serum clusterin level were evaluated in each subject. Results: Lower MMSE score and higher serum clusterin concentration were observed in mild-to-moderate COPD patients, while the lowest MMSE score and the highest serum clusterin level were found in severe COPD patients when compared with control subjects. MMSE score is positively correlated with arterial oxygen tension and is inversely associated with serum clusterin level in both mild-to-mod-
\end{abstract}

erate and severe COPD patients. Furthermore, MMSE scores and serum clusterin concentrations were correlated with forced expiratory volume in $1 \mathrm{~s}$ in severe COPD patients. Conclusion: Cognitive impairment was found in COPD patients. It is associated with the classification of disease severity, hypoxemia and serum clusterin level. An increased serum clusterin level may be a relevant peripheral biomarker of cognitive dysfunction in COPD patients.

Copyright $\odot 2012$ S. Karger AG, Basel

\section{Introduction}

Chronic obstructive pulmonary disease (COPD) is a primary airway inflammatory disease characterized by largely irreversible airflow limitation which results in hypoxemia and hypercapnia. Meanwhile, systemic inflammation has been considered to be one of the important factors linking COPD and related systemic manifestations [1-4]. The central nervous system, in particular, is vulnerable to hypoxemic insults and systemic inflammatory stress. Some studies have shown that COPD patients exhibit earlier cognitive decline in age and health status than expected $[5,6]$. However, the mechanisms involved in the impairment of cognition and the relevant factors are complex and not fully understood $[7,8]$.

\section{KARGER}

Fax +4161306 1234

E-Mail karger@karger.ch

www.karger.com (c) 2012 S. Karger AG, Basel

0025-7931/13/0852-0098\$38.00/0

Accessible online at:

www.karger.com/res
Guang-He Fei, MD, PhD

Pulmonary Department

First Affiliated Hospital of Anhui Medical University

Hefei, Anhui 230022 (China)

E-Mail guanghefei@126.com 
Clusterin, also known as apolipoprotein J, is expressed in most human tissues. It has two protein isoforms, namely a secreted heterodimeric glycoprotein and a truncated nuclear form [9]. Clusterin plays many roles in numerous cell types. Its effects are largely associated with its prominent ability to bind to hydrophobic regions of partially unfolded proteins, thus inhibiting protein aggregation and precipitation [10]. Previous studies have demonstrated that the peripheral clusterin level is elevated in several neuropathological conditions involving cognitive dysfunction and chronic inflammation of the brain [11]. Clusterin not only participates in the progression of pathological changes in incipient stages of mild cognitive impairment (MCI) but is also associated with the severity of Alzheimer's disease (AD) [12]. However, whether clusterin plays a role in the decline in cognition in COPD patients has not been reported.

In this study, we evaluated the cognitive performance and concentration of serum clusterin in COPD patients at different stages, as well as associations between the cognitive states, pulmonary function parameters, arterial blood gases and serum clusterin concentrations.

\section{Material and Methods}

\section{Subjects}

Eighty-nine subjects, including 27 mild-to-moderate COPD patients, 35 severe COPD patients and 27 control subjects, participated in the present study. The 3 groups were matched for age, sex, education level and body mass index (BMI). The COPD patients came from the First Affiliated Hospital of Anhui Medical University. The diagnosis and classification of COPD were made according to the Global Initiative for Chronic Obstructive Lung Disease 2010 guidelines [13]. All patients were treated only with necessary medications, i.e. antibiotics (levofloxacin, cefuroxime, amoxicillin/clavulanate potassium), $\beta 2$ adrenoreceptor agonists (salbutamol, salmeterol, terbutaline), ambroxol and oxygen therapy. Exclusion criteria were as follows: previous admission to an intensive care unit or an experience with mechanical ventilation, dementia, sleep disorders, obstructive sleep apnea, diabetes mellitus, head injury, psychiatric disorders (depression, anxiety disorders, schizophrenia or alcohol abuse) and use of any drugs which might affect cognitive performance (including anticholinergic medications, psychoactive drugs, long-acting benzodiazepines or tricyclic antidepressants, anticonvulsants, histamine $\mathrm{H} 2$ receptor antagonists and nonsteroidal anti-inflammatory agents). All participants were assessed by a complete physical examination by 3 raters including a respiratory physician, a cardiologist and a neuropsychologist. All subjects had given written informed consent to participate and were told of the possible risks of the study; the protocol was approved by the Human Investigation Committee of Anhui Medical University. The study was performed from February 1 to November 11, 2011.

\section{Pulmonary Function Tests}

Standardized pulmonary function tests were performed using a dry spirometer device (Erich Jaeger GmbH, Hoechberg, Germany). After inhaling salbutamol (Ventolin, GlaxoSmithKline, London, UK), each subject underwent a forced spirometry to obtain the following parameters: forced vital capacity (FVC), forced expiratory volume in $1 \mathrm{~s}\left(\mathrm{FEV}_{1}\right)$ and $\mathrm{FEV}_{1} / \mathrm{FVC}$ ratio. Subjects with $\mathrm{FEV}_{1}$ higher than $50 \%$ predicted but lower than $80 \%$ predicted were classified as the mild-to-moderate group; subjects with $\mathrm{FEV}_{1}$ lower than $50 \%$ predicted were classified as the severe group according to Global Initiative for Chronic Obstructive Lung Disease 2010 criteria.

\section{Arterial Blood Gas Analysis}

The arterial oxygen tension $\left(\mathrm{PaO}_{2}\right)$, arterial carbon dioxide tension and blood oxygen saturation were evaluated for each subject using a Stat Profile Critical Care Xpress (Nova Biomedical, Waltham, Mass., USA) while patients breathed room air in the supine position.

\section{Assessment of Cognitive Ability}

The Mini-Mental State Examination (MMSE) was used to evaluate the cognitive function of each subject, whenever the subjects could cooperate adequately. This instrument explores spatial and temporal orientation, short- and long-term verbal memory, attention, verbal attention and practical ability in 12 items and 30 questions, enabling a rapid evaluation of cognitive status with a fairly high sensitivity, specificity and reproducibility (sensitivity $80-90 \%$, specificity $80-100 \%)$. The correct answer to one question gives 1 score point (range $0-30$ ). A score below 24 indicates MCI. All examinations were performed by a trained neuropsychologist.

\section{Measurement of Serum Clusterin Concentration}

Venous blood samples $(5 \mathrm{ml})$ were centrifuged for $20 \mathrm{~min}$ at $3,000 \mathrm{rpm}$, and the supernatants were aliquoted and stored at $-20^{\circ} \mathrm{C}$ until studied. A commercial enzyme-linked immunosorbent assay kit (R\&D Biosystems, USA) was used for quantification of human clusterin concentration according to the manufacturer's instructions. The reference range of clusterin in human serum is $6.24-400 \mu \mathrm{g} / \mathrm{ml}$. The intraassay and interassay variation coefficients were $3.4-3.7 \%$ and $7.2-8.4 \%$, respectively. The established norm of serum clusterin level ranges from 90 to $220 \mu \mathrm{g} / \mathrm{ml}$. All blood samples were collected around 6.30 a.m. in a regular examination room with the same lighting.

\section{Statistical Analysis}

The clinical characteristics of subjects were compared using a $\chi^{2}$ test for categorical variables. Statistical significance of the differences between mean values from each group was tested using one-way analysis of variance for variables with normal distributions and a Kruskal-Wallis test otherwise. The Pearson correlation test was used to verify the relationship between numerical variables with normal distributions, while the Spearman rank correlation test was applied to nonparametric variables. The analysis was performed using Graphpad Prism 5. Values of $\mathrm{p}<0.05$ were considered to be significant. 
Table 1. Demographic characteristics in the control group and mild-to-moderate and severe COPD groups

\begin{tabular}{|c|c|c|c|c|}
\hline Age, years & $66.26 \pm 7.08$ & $70.48 \pm 7.75$ & $68.20 \pm 7.82$ & $0.13^{\mathrm{a}}$ \\
\hline Females/males, $\mathrm{n}$ & $9 / 18$ & $7 / 20$ & $10 / 25$ & $0.83^{\mathrm{b}}$ \\
\hline Smoking status, $\%$ & & & & $0.22^{\mathrm{b}}$ \\
\hline Never smoked & 40.74 & 33.33 & 28.57 & \\
\hline \multicolumn{5}{|c|}{ Cigarettes smoked, pack-years } \\
\hline Current smoker & $33.11 \pm 12.97$ & $32.00 \pm 9.12$ & $35.08 \pm 12.26$ & $0.90^{\mathrm{a}}$ \\
\hline Exsmoker & $28.93 \pm 7.35$ & $30.85 \pm 7.37$ & $34.50 \pm 4.10$ & $0.16^{\mathrm{a}}$ \\
\hline Education, years & $7.00 \pm 4.92$ & $6.78 \pm 5.10$ & $6.51 \pm 4.96$ & $0.93^{\mathrm{a}}$ \\
\hline BMI & $23.59 \pm 2.05$ & $22.54 \pm 3.48$ & $21.96 \pm 3.49$ & $0.13^{\mathrm{a}}$ \\
\hline Cardiovascular disease, $\%$ & 33.33 & 51.85 & 45.71 & $0.37^{b}$ \\
\hline
\end{tabular}

Data are presented as means $\pm \mathrm{SD}$, except where indicated otherwise. Cardiovascular disease includes hypertension, coronary artery disease and congestive heart failure.

a One-way analysis of variance. ${ }^{b} \chi^{2}$ test.

Table 2. Pulmonary function tests, cognitive state examination and the concentration of serum clusterin in the control group and mild-to-moderate and severe COPD groups

\begin{tabular}{|c|c|c|c|c|}
\hline Test parameter & $\begin{array}{l}\text { Control group } \\
(\mathrm{n}=27)\end{array}$ & $\begin{array}{l}\text { Mild-to-moderate } \\
\text { COPD group }(n=27)\end{array}$ & $\begin{array}{l}\text { Severe COPD } \\
\text { group }(n=35)\end{array}$ & $\mathrm{p}$ value \\
\hline $\mathrm{FEV}_{1}, \%$ predicted & $107.14 \pm 15.88$ & $60.52 \pm 6.26^{* *}$ & $34.95 \pm 9.32^{* *,++}$ & $<0.01$ \\
\hline $\mathrm{FEV}_{1} / \mathrm{FVC}$ & $90.02 \pm 8.52$ & $61.26 \pm 6.24^{* *}$ & $50.03 \pm 11.43^{* *,++}$ & $<0.01$ \\
\hline $\mathrm{PaO}_{2}, \mathrm{~mm} \mathrm{Hg}$ & $90.62 \pm 6.52$ & $73.13 \pm 8.16^{* *}$ & $67.54 \pm 12.13^{* *,++}$ & $<0.01$ \\
\hline $\mathrm{PaCO}_{2}, \mathrm{~mm} \mathrm{Hg}$ & $36.98 \pm 2.86$ & $38.29 \pm 5.71^{*}$ & $47.37 \pm 11.73^{* *,++}$ & $<0.01$ \\
\hline MMSE score & $27.59 \pm 2.89$ & $24.78 \pm 1.89^{* *}$ & $22.94 \pm 2.70^{* *,++}$ & $<0.01$ \\
\hline Clusterin, $\mu \mathrm{g} / \mathrm{ml}$ & $121.30 \pm 13.56$ & $146.60 \pm 13.90^{* *}$ & $167.50 \pm 18.13^{* *,++}$ & $<0.01$ \\
\hline
\end{tabular}

Data are presented as means \pm SD. p values were calculated by one-way analysis of variance, except where indicated otherwise.

${ }^{*} \mathrm{p}>0.05,{ }^{* *} \mathrm{p}<0.01$ vs. control group; ${ }^{+} \mathrm{p}>0.05,{ }^{++} \mathrm{p}<0.01$ vs. mild-to-moderate group. $\mathrm{PaCO} 2=$ Arterial carbon dioxide tension; $\mathrm{SaO}_{2}=$ blood oxygen saturation.

a Medians (interquartile range). ${ }^{\mathrm{b}}$ Kruskal-Wallis test.

\section{Results}

\section{Demographic Characteristics in the Control Group} and Mild-to-Moderate and Severe COPD Groups

Demographic features of the control group and COPD groups are shown in table 1. The three groups were statistically similar with respect to age, sex, education level, smoking, BMI and cardiovascular disease. This statistical similarity reflected matching $(\mathrm{p}>0.05$ in all cases).

\section{Relationship between COPD and the Risk of Cognitive Impairment}

Table 2 shows that the MMSE score was significantly lower in the mild-to-moderate $(\mathrm{p}<0.01)$ and severe COPD groups $(\mathrm{p}<0.01)$ compared with the score in the control group. Furthermore, the MMSE score declined significantly in the severe group compared with that in the mild-to-moderate group ( $\mathrm{p}<0.01)$. 
Table 3. Relationships between the relative test values and MMSE score in the groups with COPD of different severity

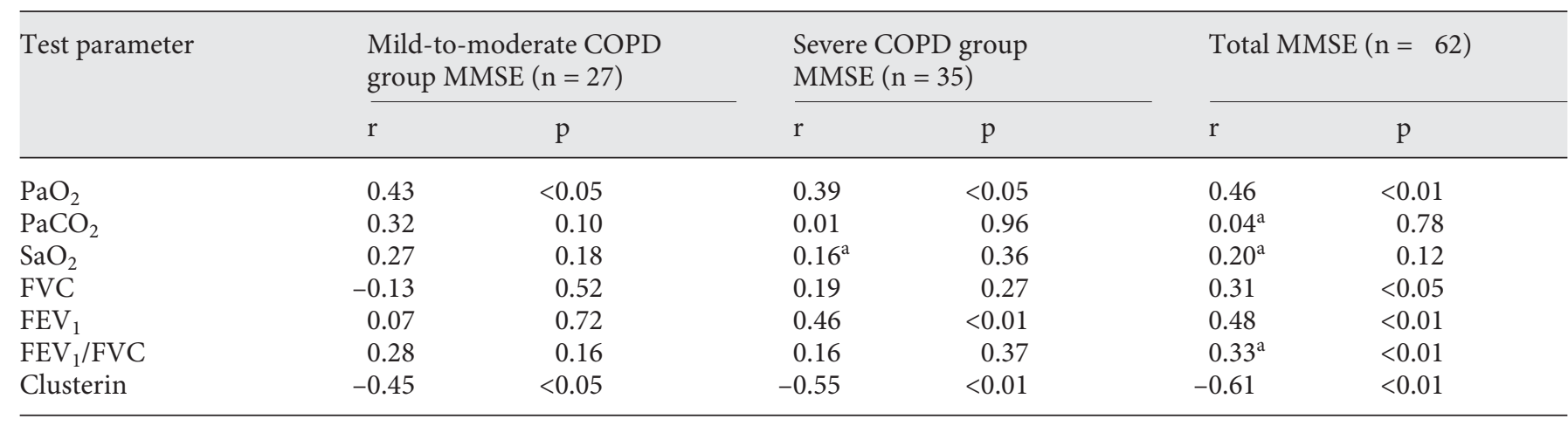

$\mathrm{PaCO}_{2}=$ Arterial carbon dioxide tension; $\mathrm{SaO}_{2}=$ blood oxygen saturation; $\mathrm{r}=$ Pearson correlation coefficient (except where indicated otherwise).

a Spearman rank correlation coefficient.

Table 4. Relationships between the relative test values and the concentration of serum clusterin in the groups with COPD of different severity

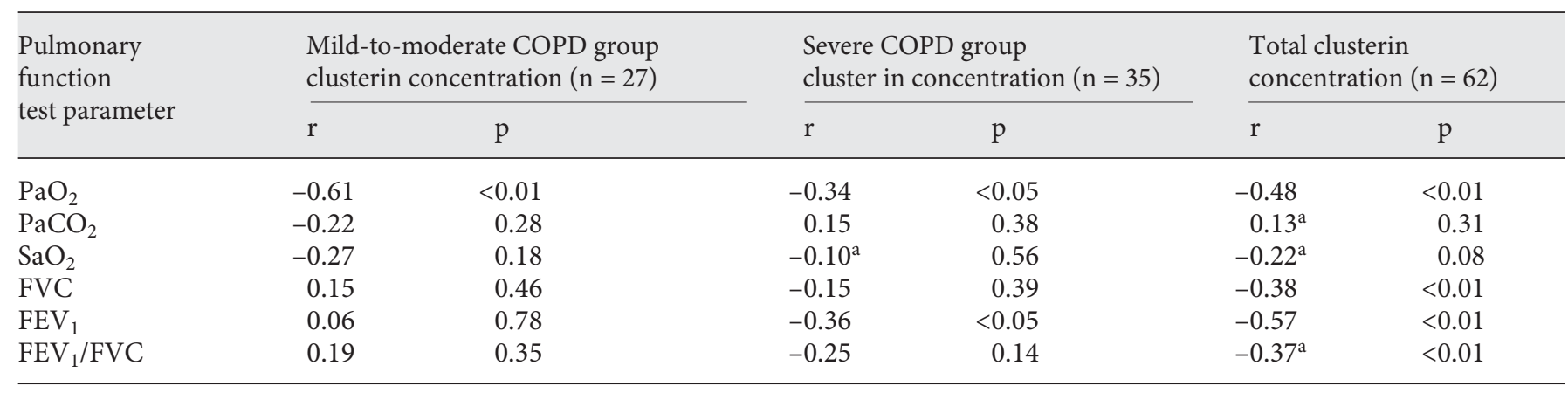

$\mathrm{PaCO}_{2}=$ Arterial carbon dioxide tension; $\mathrm{SaO}_{2}=$ blood oxygen saturation; $\mathrm{r}=$ Pearson correlation coefficient (except where indicated otherwise).

a Spearman rank correlation coefficient.

Relationship between COPD and the Concentration of Serum Clusterin

Table 2 shows that the concentrations of serum clusterin increased significantly in the mild-to-moderate $(\mathrm{p}<0.01)$ and severe COPD groups $(\mathrm{p}<0.01)$ compared with the control group. Moreover, the serum clusterin concentration was significantly higher in the severe COPD group than that in the mild-to-moderate COPD group $(\mathrm{p}<0.01)$.

\section{Correlations among Cognitive Function, Pulmonary}

Function, Arterial Blood Gases and Serum Clusterin

Level

Tables 3 and 4 show the correlations among MMSE scores, pulmonary function parameters, arterial blood gases and the concentration of serum clusterin in COPD patients. The MMSE score was correlated with $\mathrm{PaO}_{2}(\mathrm{r}=$ $0.43, \mathrm{p}<0.05)$ and serum clusterin level $(\mathrm{r}=-0.45, \mathrm{p}<$ 0.05 ) in the mild-to-moderate COPD group (fig. 1), while the MMSE score was associated with $\mathrm{PaO}_{2}, \mathrm{FEV}_{1}$ and serum clusterin concentration $(\mathrm{r}=0.39, \mathrm{p}<0.05 ; \mathrm{r}=0.46$, $\mathrm{p}<0.01 ; \mathrm{r}=-0.55, \mathrm{p}<0.01$, respectively) in the severe COPD group (fig. 2). The MMSE score was further correlated with $\mathrm{PaO}_{2}, \mathrm{FEV}_{1}$ and serum clusterin concentration $(\mathrm{r}=0.46, \mathrm{p}<0.01 ; \mathrm{r}=0.48, \mathrm{p}<0.01 ; \mathrm{r}=-0.61, \mathrm{p}<$ 0.01 , respectively) and weakly associated with FVC and $\mathrm{FEV}_{1} / \mathrm{FVC}(\mathrm{r}=0.31, \mathrm{p}<0.05 ; \mathrm{r}=0.33, \mathrm{p}<0.01$, respectively) in the entire population of COPD patients (fig. 3 , table 3). The other parameters were not significantly related with the MMSE score. 


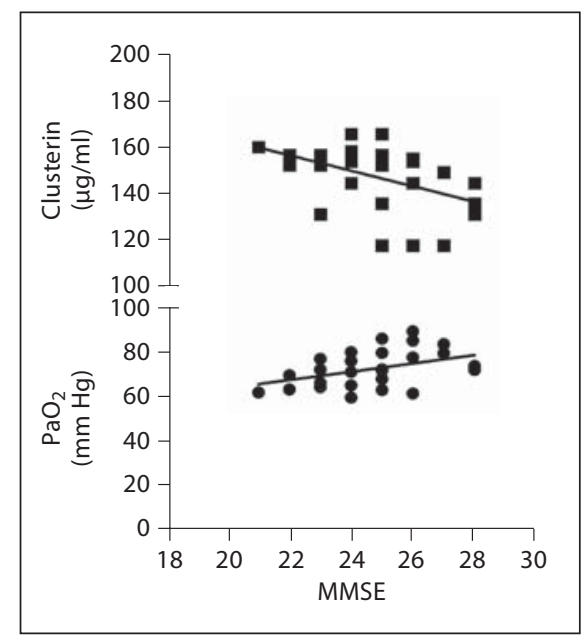

Fig. 1. Relationships and Pearson correlations between MMSE scores and the levels of $\mathrm{PaO}_{2}(\bullet)$ and serum clusterin concentrations (ם) in the mild-to-moderate COPD group. $\mathrm{PaO}_{2}: \mathrm{r}=0.43, \mathrm{p}<0.05$; clusterin: $\mathrm{r}=-0.45, \mathrm{p}<0.05$.

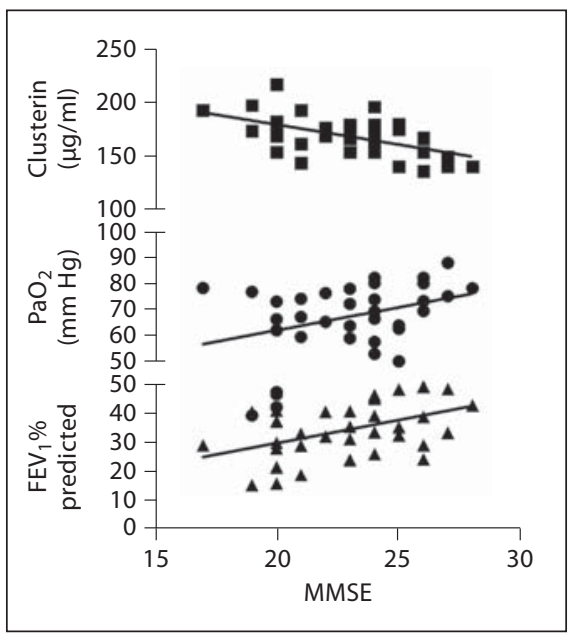

Fig. 2. Relationships and Pearson correlations between MMSE scores and $\mathrm{FEV}_{1} \%$ predicted $(\boldsymbol{\Delta})$, the levels of $\mathrm{PaO}_{2}(\boldsymbol{O})$ and serum clusterin concentrations ( $\mathbf{a})$ in the severe COPD group. $\mathrm{PaO}_{2}: \mathrm{r}=0.39, \mathrm{p}<$ $0.05 ; \mathrm{FEV}_{1}: \mathrm{r}=0.46, \mathrm{p}<0.01$; clusterin: $\mathrm{r}=$ $-0.55, \mathrm{p}<0.01$.

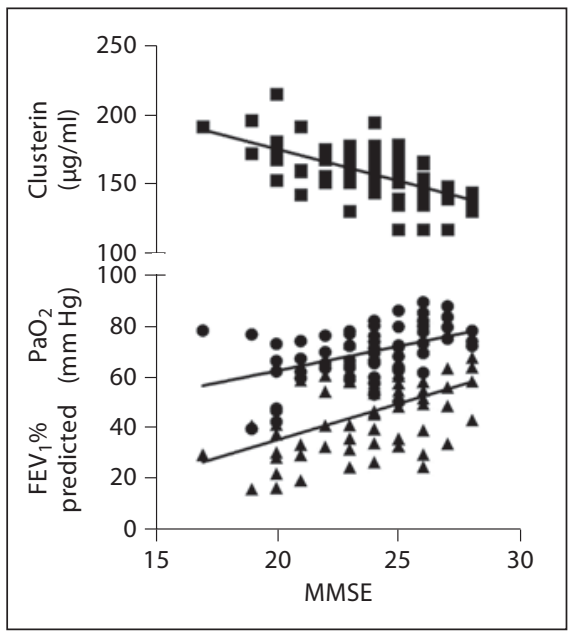

Fig. 3. Relationships and Pearson correlations between MMSE scores and $\mathrm{FEV}_{1} \%$ predicted $(\mathbf{\Delta})$, the levels of $\mathrm{PaO}_{2}(\bullet)$ and serum clusterin concentrations $(\boldsymbol{\square})$ in the entire population of COPD patients. $\mathrm{PaO}_{2}$ : $\mathrm{r}=0.46, \mathrm{p}<0.01 ; \mathrm{FEV}_{1}: \mathrm{r}=0.48, \mathrm{p}<0.01$; clusterin: $\mathrm{r}=-0.61, \mathrm{p}<0.01$.
The serum clusterin concentration was negatively correlated with $\mathrm{PaO}_{2}$ in the mild-to-moderate COPD group $(\mathrm{r}=-0.61, \mathrm{p}<0.01$; fig. 4$)$, whereas it was weakly related with both $\mathrm{PaO}_{2}$ and $\mathrm{FEV}_{1}$ in the severe COPD group $(\mathrm{r}=$ $-0.34, p<0.05 ; r=-0.36, p<0.05$, respectively; fig. 5). In addition, it was associated with $\mathrm{PaO}_{2}$ and $\mathrm{FEV}_{1}(\mathrm{r}=-0.48$, $\mathrm{p}<0.01 ; \mathrm{r}=-0.57, \mathrm{p}<0.01$, respectively; fig. 6) and weakly correlated with FVC and $\mathrm{FEV}_{1} / \mathrm{FVC}(\mathrm{r}=-0.38$, $\mathrm{p}<0.01$; $r=-0.37, p<0.01$, respectively; table 4$)$ in the entire population of COPD patients.

\section{Discussion}

In the present study, we observed overall significant cognitive deficits in COPD patients after we controlled for confounding factors, including smoking, education, BMI, sleeping and cardiovascular diseases known to affect cognition [14-19]. Therefore, consistent with previous reports, the results in the current study indicate that COPD is an independent risk factor for cognitive impairment [20-22]. We further detected that the global cognitive function was worse in severe COPD when compared to mild-to-moderate COPD. This observation shows for the first time that the cognitive decline is associated with the classification of severity during disease progression in COPD patients and provides evidence for physicians to take effective actions to prevent and treat cognitive decline in patients in the early stage of COPD.

Chronic hypoxemia is one of the most important key mechanisms that can adversely affect neuropsychological and cognitive performance [23]. COPD patients exist in a state of persistent airflow limitation and often experience poor pulmonary function which leads to chronic hypoxemia. In our study, we examined the relationships between cognitive ability and pulmonary function or arterial blood gas in mild-to-moderate and severe COPD groups, respectively. We found that $\mathrm{PaO}_{2}$ was positively correlated with cognitive ability in both groups. Consistent with our research, some earlier studies have also demonstrated that $\mathrm{PaO}_{2}$ is correlated with cognitive function, particularly with regard to attention, motor function and processing speed [5]. These findings show that the chronic hypoxemia may be involved in the cognitive impairment in COPD patients.

Interestingly, as we explored these potential harmful factors for cognitive damage in the severe COPD group, we observed that cognitive ability is not only associated with the level of $\mathrm{PaO}_{2}$ but is also positively linearly correlated with $\mathrm{FEV}_{1}$. This was also shown in the entire population of COPD patients. Some prior studies have also demonstrated that a decline in $\mathrm{FEV}_{1}$ level was related to 


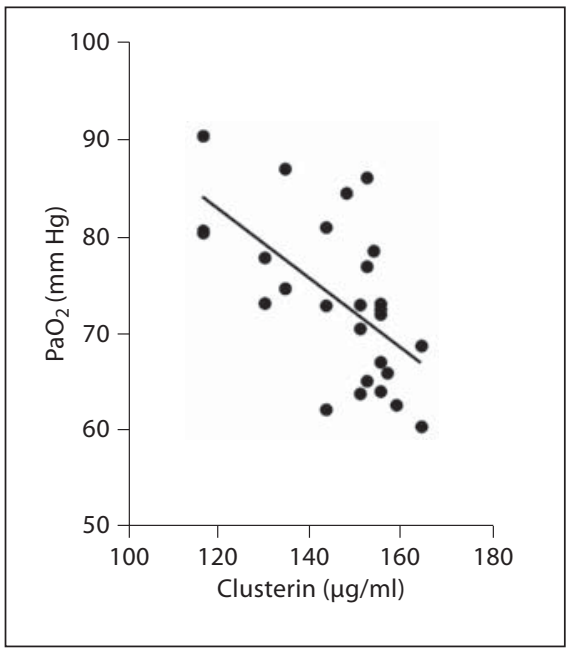

Fig. 4. Relationship and Pearson correlation between the concentrations of serum clusterin and the levels of $\mathrm{PaO}_{2}$ in the mild-to-moderate COPD group. $\mathrm{r}=-0.61$, $\mathrm{p}<0.01$.

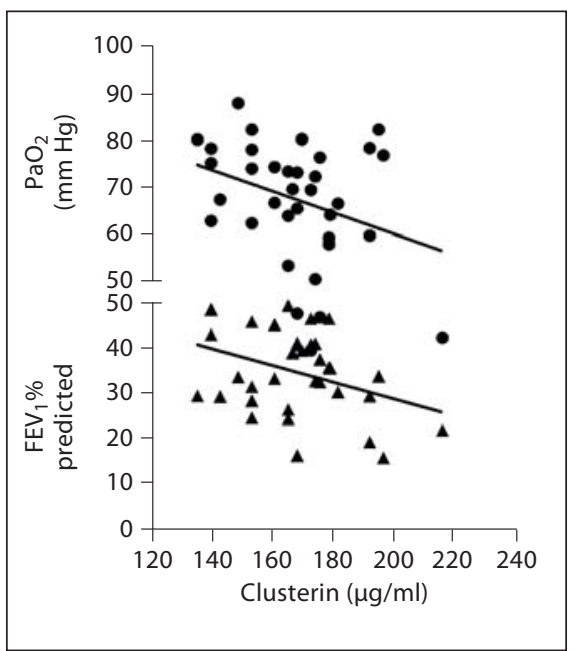

Fig. 5. Relationships and Pearson correlations between the concentrations of serum clusterin and the levels of $\mathrm{PaO}_{2}(\bullet)$ and $\mathrm{FEV}_{1} \%$ predicted $(\boldsymbol{\Delta})$ in the severe COPD group. $\mathrm{PaO}_{2}: \mathrm{r}=-0.34, \mathrm{p}<0.05 ; \mathrm{FEV}_{1}: \mathrm{r}=$ $-0.36, \mathrm{p}<0.05$.

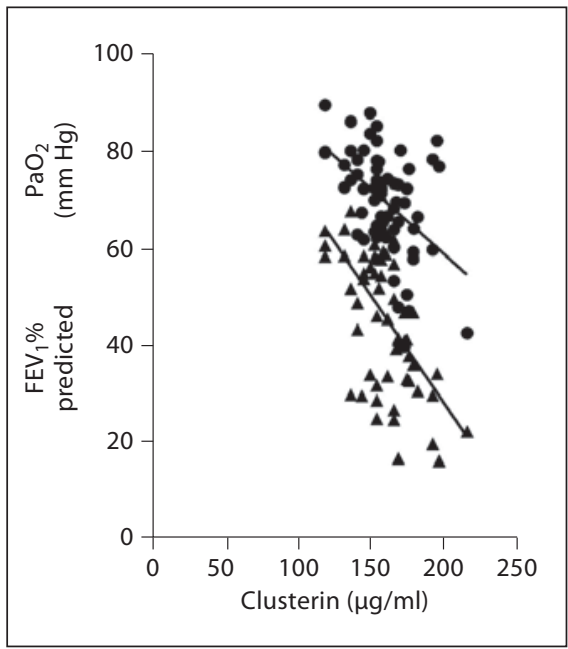

Fig. 6. Relationships and Pearson correlations between the concentrations of serum clusterin and the levels of $\mathrm{PaO}_{2}(\bullet)$ and $\mathrm{FEV}_{1} \%$ predicted $(\boldsymbol{\Delta})$ in the entire population of COPD patients. $\mathrm{PaO}_{2}: \mathrm{r}=-0.48$, $\mathrm{p}<0.01 ; \mathrm{FEV}_{1}: \mathrm{r}=-0.57, \mathrm{p}<0.01$. poor cognitive ability $[24,25]$. However, other studies have shown that lung function is not a reliable predictor of cognitive function in COPD populations [26-28]. The precise mechanisms causing the phenomenon are still unknown. Some studies have proposed that intermittent and continuous hypoxia in COPD patients, which results from poor lung function, may lead to transient deficits in the metabolism of neurotransmitters in the central nervous system [29-32]. Other studies have suggested that in the late stage of the disease, as a consequence of decreased pulmonary function, cerebral blood perfusion is reduced, which may exacerbate ischemia in some brain regions and thus may increase subcortical atrophy $[7,33]$.

However, there was no correlation between cognitive ability and $\mathrm{FEV}_{1}$ in the early stage of the disease in our present study. One possible explanation is that poor pulmonary function, hypoxia or systemic inflammation in the early stage of COPD were not as severe as in the later stage.

Recent studies have reported that MCI and AD patients have significantly higher serum clusterin levels than normal controls [11,34]. The peripheral clusterin concentration was associated with MMSE score and brain atrophy in both MCI and AD patients [10, 12, 34]. Several lines of evidence further suggest biological roles of clusterin in pathways relevant to neuropathology, in- cluding amyloid clearance, complement modulation and apoptosis [10]. In the present study, we evaluated the serum clusterin concentration and found that it is higher in COPD patients compared with that in control subjects. The pattern of the relationship between the elevated level of serum clusterin and the reduced cognitive ability in COPD patients was similar to that observed in MCI and $\mathrm{AD}$ patients $[11,34]$. These findings indicate that COPD may be one of the basic diseases of preclinical AD. Since COPD patients not only have harmful factors such as hypoxemia but also evidence of systematic inflammation such as interleukin-6, interleukin-8 and tumor necrosis factor- $\alpha[1-3,35]$, which spill over from the lung to the central nervous system, it is conceivable that some pathological changes occurring in the brain regions of COPD patients may increase the risk of AD. However, future studies are needed to address the precise mechanisms underlying this observation.

Furthermore, it is noteworthy that the level of serum clusterin was negatively correlated with cognitive ability. This finding suggests that the higher serum clusterin concentration may be a biologically relevant peripheral signature of cognitive impairment in COPD patients.

The cognitive impairment in COPD patients may occur in discrete domains. However, the MMSE, which has been proven useful and sufficient for cognitive measurements 
[2], provides a broad scale and does separate the specific cognitive functions. A neuropsychological testing battery will be considered in future studies to provide detailed analysis and quantification of mental functions of patients such as short- and long-term memory, speech and learning impairments and impaired motor, visual and spatial functions. Another shortcoming of this study is the relatively small size of the participant population, which may partially account for the weak association between some of the measurements in our results. While the number of cases will be continuously increased in our future work, we anticipate that this study will lead to the realization of cognitive impairment in COPD patients in the field.

In conclusion, our experimental results confirmed that the cognitive impairment that occurs in COPD patients was significantly associated with disease severity, hypoxemia and serum clusterin concentration. Increased serum concentrations of clusterin may be a relevant peripheral signature of cognitive dysfunction in COPD pa- tients. COPD characterized by chronic hypoxia and systematic inflammation may be one of the basic diseases of preclinical AD.

\section{Acknowledgments}

The authors would like to sincerely thank Rui Xu, Rong-huai $\mathrm{Li}$ and Xian-wei $\mathrm{Hu}$ for their assistance with the recruitment and clinical assessment of the participants. We thank Mr. Harsh Bhavsar from Rugters University for careful editing of the manuscript.

\section{Financial Disclosure and Conflicts of Interest}

This work was supported by The National Natural Science Foundation of China (No. 81070020), The Natural Science Grant of Anhui Province (No. 090413119) and The Natural Science Grant of the Education Bureau of Anhui Province (No. KJ2008A158).

\section{References}

1 Barnes PJ, Celli BR: Systemic manifestations and comorbidities of COPD. Eur Respir J 2009;33:1165-1185.

-2 van Eeden SF, Sin DD: Chronic obstructive pulmonary disease: a chronic systemic inflammatory disease. Respiration 2008;75: 224-238.

-3 Cazzola M, Bettoncelli G, Sessa E, Cricelli C, Biscione G: Prevalence of comorbidities in patients with chronic obstructive pulmonary disease. Respiration 2010;80:112119.

4 Jan Ankersmit H, Nickl S, Hoeltl E, Toepker M, Lambers C, Mitterbauer A, Kortuem B, Zimmermann M, Moser B, Bekos C, Steinlechner B, Hofbauer H, Klepetko W, Schenk P, Dome B: Increased serum levels of HSP27 as a marker for incipient chronic obstructive pulmonary disease in young smokers. Respiration 2012;83:391-399.

$\checkmark 5$ Dodd JW, Getov SV, Jones PW: Cognitive function in COPD. Eur Respir J 2010;35:913922.

6 Lima OM, Oliveira-Souza R, Santos Oda R, Moraes PA, Sá LF, Nascimento OJ: Subclinical encephalopathy in chronic obstructive pulmonary disease. Arq Neuropsiquiatr 2007;65:1154-1157.

-7 Antonelli Incalzi R, Marra C, Giordano A, Calcagni ML, Cappa A, Basso S, Pagliari G, Fuso L: Cognitive impairment in chronic obstructive pulmonary disease - a neuropsychological and spect study. J Neurol 2003; 250:325-332.
-8 Borson S, Scanlan J, Friedman S, Zuhr E, Fields J, Aylward E, Mahurin R, Richards T, Anzai Y, Yukawa M, Yeh S: Modeling the impact of COPD on the brain. Int J Chron Obstruct Pulmon Dis 2008;3:429-434.

-9 Trougakos IP, Gonos ES: Chapter 9: oxidative stress in malignant progression: the role of Clusterin, a sensitive cellular biosensor of free radicals. Adv Cancer Res 2009;104:171-210.

10 Nuutinen T, Suuronen T, Kauppinen A, Salminen A: Clusterin: a forgotten player in Alzheimer's disease. Brain Res Rev 2009;61: 89-104.

11 Thambisetty M, An Y, Kinsey A, Koka D, Saleem M, Güntert A, Kraut M, Ferrucci L, Davatzikos $\mathrm{C}$, Lovestone S, Resnick SM: Plasma clusterin concentration is associated with longitudinal brain atrophy in mild cognitive impairment. Neuroimage 2012;59:212-217.

12 Thambisetty M, Simmons A, Velayudhan L, Hye A, Campbell J, Zhang Y, Wahlund LO, Westman E, Kinsey A, Güntert A, Proitsi P, Powell J, Causevic M, Killick R, Lunnon K, Lynham S, Broadstock M, Choudhry F, Howlett DR, Williams RJ, Sharp SI, Mitchelmore C, Tunnard C, Leung R, Foy C, O'Brien D, Breen G, Furney SJ, Ward M, Kloszewska I, Mecocci P, Soininen H, Tsolaki M, Vellas B, Hodges A, Murphy DG, Parkins S, Richardson JC, Resnick SM, Ferrucci L, Wong DF, Zhou Y, Muehlboeck S, Evans A, Francis PT, Spenger C, Lovestone S: Association of plasma clusterin concentration with severity, pathology, and progression in Alzheimer disease. Arch Gen Psychiatry 2010;67:739-748.
13 Rodriguez-Roisin R, Anzueto A, Bourbean J, DeGuia TS, Hui D, Jenkin C, Martinez F, Mishima M, Montes de Oca M, Stockley R, van Weel C, Vestbo J: Global initiative for chronic obstructive lung disease. GOLD Executive Committee 2010. http://www. goldcopd.org/uploads/users/files/ GOLDReport_April112011.pdf.

14 Swan GE, Lessov-Schlaggar CN: The effects of tobacco smoke and nicotine on cognition and the brain. Neuropsychol Rev 2007; 17: 259-273.

15 Isajevs S, Taivans I, Svirina D, Strazda G, Kopeika U: Patterns of inflammatory responses in large and small airways in smokers with and without chronic obstructive pulmonary disease. Respiration 2011;81:362-371.

16 Alonso A, Mosley TH Jr, Gottesman RF, Catellier D, Sharrett AR, Coresh J: Risk of dementia hospitalisation associated with cardiovascular risk factors in midlife and older age: the Atherosclerosis Risk in Communities (ARIC) study. J Neurol Neurosurg Psychiatry 2009;80:1194-1201.

17 Bawden FC, Oliveira CA, Caramelli P: Impact of obstructive sleep apnea on cognitive performance. Arq Neuropsiquiatr 2011;69: 585-589.

18 Paulo AC, Sampaio A, Santos NC, Costa PS, Cunha P, Zihl J, Cerqueira J, Palha JA, Sousa $\mathrm{N}$ : Patterns of cognitive performance in healthy ageing in Northern Portugal: a cross-sectional analysis. PLoS One 2011; 6:e24553. 
19 Mueller K, Anwander A, Möller HE, Horstmann A, Lepsien J, Busse F, Mohammadi S, Schroeter ML, Stumvoll M, Villringer A, Pleger B: Sex-dependent influences of obesity on cerebral white matter investigated by diffusion-tensor imaging. PLoS One 2011; 6:e18544.

20 Incalzi RA, Gemma A, Marra C, Capparella O, Fuso L, Carhonin P: Verbal memory impairment in COPD: its mechanisms and clinical relevance. Chest 1997;112:1506-1513.

-21 Hung WW, Wisnivesky JP, Siu AL, Ross JS: Cognitive decline among patients with chronic obstructive pulmonary disease. Am J Respir Crit Care Med 2009;180:134-137.

$\$ 22$ Ozge C, Ozge A, Unal O: Cognitive and functional deterioration in patients with severe COPD. Behav Neurol 2006;17:121-130.

23 Thakur N, Blanc PD, Julian LJ, Yelin EH, Katz PP, Sidney S, Iribarren C, Eisner MD: COPD and cognitive impairment: the role of hypoxemia and oxygen therapy. Int J Chron Obstruct Pulmon Dis 2010;5:263-269.

-24 Chyou PH, White LR, Yano K, Sharp DS, Burchfiel CM, Chen R, Rodriguez BL, Curb JD: Pulmonary function measures as predictors and correlates of cognitive functioning in later life. Am J Epidemiol 1996;143:750756.
25 Sachdev PS, Anstey KJ, Parslow RA, Wen W, Maller J, Kumar R, Christensen H, Jorm AF: Pulmonary function, cognitive impairment and brain atrophy in a middle-aged community sample. Dement Geriatr Cogn Disord 2006;21:300-308.

-26 Etnier J, Johnston R, Dagenbach D, Pollard RJ, Rejeski WJ, Berry M: The relationships among pulmonary function, aerobic fitness, and cognitive functioning in older COPD patients. Chest 1999;116:853-960.

27 Antonelli-Incalzi R, Imperiale C, Bellia V, Catalano F, Scichilone N, Pistelli R, Rengo F; SaRA Investigators: Do GOLD stages of COPD severity really correspond to differences in health status? Eur Respir J 2003;22: 444-449.

28 Liesker JJ, Postma DS, Beukema RJ, ten Hacken NH, van der Molen T, Riemersma RA, van Zomeren EH, Kerstjens HA: Cognitive performance in patients with COPD. Respir Med 2004;98:351-356.

29 Nel A: Atmosphere. Air pollution-related illness: effects of particles. Science 2005;308: 804-806.
30 Maccioni RB, Rojo LE, Fernández JA, Kuljis RO: The role of neuroimmunomodulation in Alzheimer's disease. Ann NY Acad Sci 2009; 1153:240-246.

31 Gibson GE, Pulsinelli W, Blass JP, Duffy TE: Brain dysfunction in mild to moderate hypoxia. Am J Med 1981;70:1247-1254.

32 Weuve J, Glymour MM, Hu H, Sparrow D, Spiro A 3rd, Vokonas PS, Litonjua AA: Forced expiratory volume in 1 second and cognitive aging in men. J Am Geriatr Soc 2011;59:1283-1292.

33 Ortapamuk H, Naldoken S: Brain perfusion abnormalities in chronic obstructive pulmonary disease: comparison with cognitive impairment. Ann Nucl Med 2006;20:99-106.

- 34 Schrijvers EM, Koudstaal PJ, Hofman A, Breteler MM: Plasma clusterin and the risk of Alzheimer disease. JAMA 2011;305:13221326.

35 van Durme YM, Lahousse L, Verhamme KM, Stolk L, Eijgelsheim M, Loth DW, Uitterlinden AG, Breteler MM, Joos GF, Hofman A, Stricker BH, Brusselle GG: Mendelian randomization study of interleukin- 6 in chronic obstructive pulmonary disease. Respiration 2011;82:530-538. 